Research $_{\text {Afer }} \longrightarrow$ FOOD SCIENCE e ISSN-2230-9403 - Visit us : www.researchjournal.co.in Volume 8 | Issue 1 | April, 2017 | 112-118 DOI : 10.15740/HAS/FSRJ/8.1/112-118

\title{
Nutritional and sensory quality of wheat bread supplemented with stabilized rice bran
}

\author{
J.K. Sangle, A.R. Sawate, B.M. Patil and R.B. Kshirsagar
}

This project was designed to evaluate the suitability of stabilized rice bran for the supplementation of bread. Freshly milled rice bran was treated with autoclave heating for its stabilization. The effect of stabilized rice bran supplementation on nutritional and sensory properties of wheat bread was determined. Blends of wheat flour and rice bran (95:5, 90:10, 85:15 and 80:20) were used to bake bread with 100 per cent wheat flour as control. Thereafter, proximate, mineral composition and sensory properties of the bread loaves were determined, using standard methods of analysis. The moisture content, crude protein, crude fat, crude fibre and ash of the composite bread loaves increased significantly $(\mathrm{p}<$ 0.05 ) from 31.12 per cent to 33.98 per cent, 11.87 per cent to 13.38 per cent, 1.52 per cent to 3.95 per cent, 0.82 per cent to 2.65 per cent and 1.52 per cent to 2.09 per cent, respectively; while carbohydrate content decreased with increased level of supplementation from 53.13 per cent to 43.92 per cent. Mineral content of the bread increased significantly $(\mathrm{p}<$ 0.05 ) with increased level of supplementation from $6.44 \mathrm{mg} / 100 \mathrm{~g}$ to $15.61 \mathrm{mg} / 100 \mathrm{~g}$ (Iron), $80.64 \mathrm{mg} / 100 \mathrm{~g}$ to $221.22 \mathrm{mg} / 100 \mathrm{~g}$ (Potassium), $84.47 \mathrm{mg} / 100 \mathrm{~g}$ to $153.41 \mathrm{mg} / 100 \mathrm{~g}$ (Calcium), $13.67 \mathrm{mg} / 100 \mathrm{~g}$ to $161.86 \mathrm{mg} / 100 \mathrm{~g}$ (Magnesium) and $2.24 \mathrm{mg} /$ $100 \mathrm{gm}$ to $4.13 \mathrm{mg} / 100 \mathrm{~g}$ (Zinc). However, there was a significant decrease $(\mathrm{p}<0.05)$ in sodium with increased level of supplementation from $304.31 \mathrm{mg} / 100 \mathrm{~g}$ to $227.24 \mathrm{mg} / 100 \mathrm{~g}$. The control sample of bread was acceptable similar to 15 per cent rice bran supplemented bread. The bread supplemented with stabilized rice bran at 20 per cent got the lowest sensory score than other composite and control bread. But, all the composite bread samples had significantly $(\mathrm{p}<0.05)$ higher values for nutritional parameters. It can be concluded from the results that upto 15 per cent stabilized rice bran can be successfully incorporated in the bread to improve the sensory and nutritional attributes.

Key Words : Composite bread, Rice bran, Nutritional quality, Supplementation, Sensory quality

How to cite this article : Sangle, J.K., Sawate, A.R., Patil, B.M. and Kshirsagar, R.B. (2017). Nutritional and sensory quality of wheat bread supplemented with stabilized rice bran. Food Sci. Res. J., 8(1): 112-118, DOI : 10.15740/HAS/FSRJ/8.1/112-118.

\footnotetext{
MEMBERS OF RESEARCH FORUM

Author for correspondence :

J.K. SANGLE, Department of Food Engineering, College of Food Technology, Vasantrao Naik Marathwada Krishi Vidyapeeth, PARBHANI (M.S.) INDIA

Associate Authors' :

A.R. SAWATE, B.M. PATIL AND R.B. KSHIRSAGAR, Department of Food

Engineering, College of Food Technology, Vasantrao Naik Marathwada Krishi Vidyapeeth, PARBHANI (M.S.) INDIA
} 